\title{
INOVASI, ANGKA KELAHIRAN PERUSAHAAN SERTA PENGARUH MODERASI APLIKASI PATEN
}

\author{
INNOVATION, BIRTH RATE OF ENTERPRISES \\ AND THE INFLUENCE OF MODERATION OF PATENT APPLICATIONS
}

\author{
Onny Setiawan', ${ }^{1}$ Okalesa $^{2}$, Sarli Rahman ${ }^{3}$ \\ Institut Bisnis dan Teknologi Pelita Indonesia ${ }^{1,2,3}$ \\ onny.setiawan@1ecturer.pelitaindonesia.ac.id ${ }^{1}$
}

\begin{abstract}
Innovation is the foundation of a company's life. The purpose of this study is to understand the effect of innovation on the birth rate of enterprises by using macro data in a country. Data on the birth rate of a company is used to see the effectiveness of a country's innovation in increasing the number of entrepreneurs in its country. The results showed that of the 16 OECD member countries that became the study sample it was found that the innovation activities undertaken by these countries, especially $R \& D$ activities, were not proven to be effective and applicable in creating new businesses. Meanwhile, the patent application only helps in terms of changing the direction of its influence, which was negative to positive initially, but not proven statistically significant.
\end{abstract}

Keyword : Innovation, R\&D Expenditure, Number of Patent Applications, Birth Rate of Enterprises, OECD.

\begin{abstract}
ABSTRAK
Inovasi merupakan fondasi kehidupan sebuah perusahaan. Tujuan dari penelitian ini untuk memahami pengaruh inovasi terhadap tingkat kelahiran perusahaan dengan menggunakan data makro di sebuah negara. Data tingkat kelahiran perusahaan digunakan untuk melihat keefektifan inovasi yang dilakukan sebuah negara dalam meningkatkan jumlah entrepreneur di negaranya. Hasil penelitian menunjukan bahwa dari 16 negara anggota OECD yang menjadi sampel penelitian diketahui bahwa aktivitas inovasi yang dilakukan oleh negara-negara tersebut, terutama aktivitas R\&D tidak terbukti efektif dan aplikatif dalam menciptakan usaha-usaha baru. Sementara itu, aplikasi paten hanya membantu dalam hal mengubah arah pengaruhnya, yang awalnya negatif menjadi positif, tetapi tidak terbukti signifikan secara statistik.
\end{abstract}

Kata Kunci : Inovasi, Belanja R\&D, Jumlah Aplikasi Paten, Angka Kelahiran Perusahaan, OECD.

\section{PENDAHULUAN}

Inovasi merupakan fondasi
kehidupan sebuah perusahaan. Dibandingkan dengan perusahaan yang tidak inovatif, ternyata perusahaanperusahaan yang inovatif memiliki peluang untuk hidup $11 \%$ lebih lama, alasannya adalah karena dengan melakukan inovasi sebuah perusahaan mendapat maanfaat dari premi inovasi (Helmers \& Rogers, 2010) berupa monopoli penjualan produk baru sehingga dapat meningkatkan profitabilitas. Dengan dasar itulah 
banyak penelitian terdahulu mengukur kemampuan hidup sebuah perusahaan dari kinerja keuagan jangka pendek perusahaan. Ketika banyak penelitian sebelumnya melihat hubungan antara aktivitas inovasi dengan kelangsungan hidup perusahaan dari sisi kesuksesan inovasi seperti yang telah dijelaskan sebelumnya, maka pada penelitian ini kami akan melihat bagaimana pengaruh aktivitas inovasi di sebuah negara dengan kemunculan atau kelahiran perusahaan-perusahaan baru di negaranegara tersebut, karena dengan melakukan inovasi, maka persentase peluang terhadap penemuan-penemuan produk baru yang masuk pasar akan semakin tinggi, sehingga dapat memunculkan perusahaan-perusahaan baru, baik itu perusahaan yang benarbenar baru atau anak dari perusahaan yang sudah ada maupun perusahaan kemitraan yang muncul akibat dari hasil kerjasama inovasi.

Dari salah satu laporan Global Entrepreneurship Monitor (GEM) pada tahun 2016 diketahui bahwa pemerintah Austria berusaha mepromosikan dan meningkatkan angka kewirausahaan dinegaranya melalui inovasi dan pemanfaatan teknologi (Fitzsimons \& O'Gorman, 2017). Dengan berfokus pada peningkatan kapasitas inovasi dinegaranya, pemerintah Austria berharap akan banyak bermunculan ideide dan proyek-proyek baru dari generasi mudanya, yang mana jika proyek-proyek ini didanai dan didukung oleh pemerintah, maka output akhirnya yang diharapkan adalah bermunculannya para pengusaha baru. International Telecommunication Union (ITU) di dalam laporannya pada tahun 2016 menyatakan adanya hubungan antara peringkat negara dalam Global Innovation Index dan Global Entrepreneurship Index, dengan tingkat korelasi sebesar 80\% (ITU, 2016). Hal ini bisa dipahami, mengingat inovasi dengan aktivitas R\&D nya berpeluang besar untuk menghasilkan produkproduk baru yang akan masuk ke pasar (Welfens, 2011). Pernyataan ini diperkuat oleh bukti yang disampaikan didalam laporan tahunan tahun 2014 kepala penasihat ilmiah pemerintah Inggris yang menyatakan bahwa aktivitas inovasi di negara tersebut memainkan peran kunci dalam pengembangan produk baru, tidak hanya berupa produk fisik, namun juga di sektor jasa (Bennett et al., 2014). Kemunculan produk-produk baru yang merupakan buah dari aktivitas inovasi tersebut akan memperbesar peluang terhadap kemunculan perusahaanperusahaan baru. Jika produk-produk baru tersebut bersumber dari aktivitas inovasi peusahaan yang sudah berdiri, maka prodduk-produk tersebut akan menambah lini produk atau bauran produk mereka, namun jika produkproduk baru tersebut berasal dari ide calon pengusaha baru, maka tentu akan membulatkan tekad mereka untuk mendirikan sebuah perusahaan. Begitupun juga jika produk-produk baru tersebut merupakan buah dari hasil kolaborasi atau kerja sama inovasi beberapa institusi, maka hal tersebut akan memunculkan model bisnis baru dengan merek atau nama perusahaan baru (Como et al, 2016).

Berdasarkan penjelasan di atas, maka dapat dikembangkan hipotesis terkait hubungan inovasi yang diukur melalui data R\&D expenditures dan data paten terhadap kelahiran perusahaan di sebuah negara.

\section{METODE PENELITIAN}

Pada penelitian ini yang menjadi populasinya adalah 36 negara yang menjadi anggota The Organisation for Economic Co-operation and Development (OECD). Sementara itu 
sampel ditentukan dengan menggunakan teknik pengambilan sampel non probability sampling. Yaitu metode purposive sampling berdasarkan kriteria berikut:

1. Negara-negara yang dipilih harus memiliki data yang lengkap di World Bank Database (data.worldbank.org) terkait dengan data $R \& D$ expenditures dan number of patent resident selama priode $2008-2015$.

2. Negara-negara yang dipilih juga harus memiliki data tingkat kelahiran perusahaan selama priode 2008 - 2015, yang bersumber dari stats.oecd.org.

3. Untuk beberapa negara yang tidak memiliki data R\&D Expenditures (\% of GDP) pada tahun-tahun tertentu selama priode tersebut, maka diasumsikan bahwa nilainya sama dengan tahun sebelumnya. Hal ini merujuk dari data yang ditampilkan oleh UNESCO di situs UIS Tellmaps.

Dari 36 negara populasi, maka terpilih 16 negara yang memenuhi semua kriteria yang ditetapkan untuk dijadikan sampel penelitian, seperti yang tercantum pada tabel berikut:

Tabel 1. Sampel Penelitian

\begin{tabular}{clcl}
\hline No & \multicolumn{1}{c}{ Negara } & No & \multicolumn{1}{c}{ Negara } \\
\hline 1. & Australia & 9. & Netherlands \\
\hline 2. & Austria & 10. & Norway \\
\hline 3. & Czech Republic & 11. & Portugal \\
\hline 4. & Estonia & 12. & $\begin{array}{l}\text { Slovak } \\
\text { Republic }\end{array}$ \\
\hline 5. & France & 13. & Spain \\
\hline 6. & Hungary & 14. & Sweden \\
\hline 7. & Latvia & 15. & $\begin{array}{l}\text { United } \\
\text { Kingdom }\end{array}$ \\
\hline 8. & Lithuania & 16. & Romania \\
\hline Source: OECD & &
\end{tabular}

Adapun penjelasan untuk setiap variabel yang digunakan pada penelitian ini dapat dilihat pada tabel defenisi operasional berikut:
Tabel 2. Defenisi Operasional Variabel Penelitian

\begin{tabular}{ll}
\hline \multicolumn{1}{c}{ Variabel } & \multicolumn{1}{c}{ Defenisi } \\
\hline R\&D Expenditures & Pengeluaran domestik \\
$(\%)$ & untuk penelitian dan \\
& pengembangan (Litbang) \\
& yang dinyatakan sebagai \\
& persen dari PDB. \\
\hline Patent applications & Merupakan aplikasi \\
(Unit) & paten yang diajukan oleh \\
& penduduk melalui \\
& prosedur tertentu untuk \\
& hak eksklusif suatu \\
& penemuan, produk atau \\
& proses yang \\
& menyediakan cara baru \\
& dalam melakukan \\
& sesuatu atau menawarkan \\
& solusi teknis baru untuk \\
& suatu masalah. \\
\hline Birth rate of all & Jumlah kelahiran \\
enterprises (\%) & perusahaan dalam satu \\
& periode referensi dibagi \\
& dengan jumlah \\
& perusahaan yang aktif \\
& pada periode tersebut. \\
\hline
\end{tabular}

Sumber: data.worldbank.org \& stats.oecd.org

Seperti yang telah dijelaskan sebelumnya, bahwa pada penelitian ini variabel-variabel yang digunakan adalah R\&D Expenditures, patent applications (residents), death rate of all enterprises dan birth rate of all enterprises. Agar semua variabel memiliki satuan yang sama, maka variabel patent applications akan di logaritmakan, dengan kerangka pemikiran sebagai berikut:

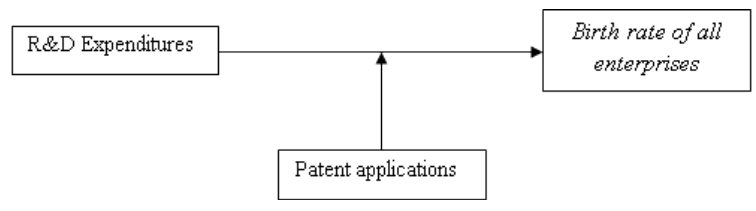

Gambar 1 : Kerangka Pemikiran

\section{HASIL DAN PEMBAHASAN}

Pada penelitian ini variabelvariabel yang digunakan adalah $R D E$, 
Log Patent, dan Birth Rate dengan hasil statistik deskriftif sebagai berikut:

Tabel 3. Statistik Deskriptif

\begin{tabular}{lrrrrrr}
\hline \multirow{2}{*}{ Country } & \multicolumn{2}{c}{ RDE } & \multicolumn{2}{c}{ Patent (Resident) } & \multicolumn{2}{c}{ Birth Rate } \\
\cline { 2 - 7 } & Mean (\%) & $\begin{array}{c}\text { Std. } \\
\text { Dev. }\end{array}$ & \multicolumn{1}{c}{ Mean (\%) } & $\begin{array}{c}\text { Std. } \\
\text { Dev. }\end{array}$ & $\begin{array}{c}\text { Mean } \\
\text { (\%) }\end{array}$ & $\begin{array}{c}\text { Std. } \\
\text { Dev. }\end{array}$ \\
\hline Australia & 2.245 & 0.161 & $2,509.250$ & 329.727 & 13.663 & 1.791 \\
\hline Austria & 2.820 & 0.205 & $2,232.000$ & 102.935 & 7.563 & 0.563 \\
\hline Czech Republic & 1.626 & 0.307 & 849.125 & 84.783 & 8.850 & 2.402 \\
\hline Estonia & 1.666 & 0.368 & 50.375 & 24.142 & 11.925 & 2.647 \\
\hline France & 2.206 & 0.068 & $14,524.625$ & 220.706 & 10.675 & 1.460 \\
\hline Hungary & 1.226 & 0.142 & 650.000 & 67.494 & 9.825 & 0.643 \\
\hline Latvia & 0.617 & 0.078 & 181.750 & 45.298 & 16.325 & 1.586 \\
\hline Lithuania & 0.903 & 0.100 & 103.625 & 12.861 & 21.313 & 3.491 \\
\hline Netherlands & 1.857 & 0.148 & $2,412.375$ & 139.658 & 10.850 & 1.149 \\
\hline Norway & 1.683 & 0.114 & $1,125.500$ & 66.024 & 8.688 & 0.613 \\
\hline Portugal & 1.406 & 0.118 & 617.125 & 160.649 & 13.613 & 1.507 \\
\hline Slovak Republic & 0.737 & 0.236 & 199.000 & 28.219 & 13.975 & 3.250 \\
\hline Spain & 1.294 & 0.050 & $3,283.500$ & 323.145 & 8.263 & 0.867 \\
\hline Sweden & 3.301 & 0.117 & $2,197.125$ & 192.142 & 7.275 & 0.420 \\
\hline United Kingdom & 1.657 & 0.029 & $15,468.250$ & 546.054 & 12.600 & 1.875 \\
\hline Romania & 0.462 & 0.057 & $1,099.625$ & 190.001 & 11.963 & 2.516 \\
\hline Sumber : Data Olahan (2020) & & & &
\end{tabular}

Dari tabel 3 diketahui bahwa negara yang memiliki tingkat kelahiran perusahaan yang tertinggi adalah Lithuania. Meskipun demikia jika dilihat dari dana yang dialokasikan oleh negara tersebut untuk aktivitas R\&D tidaklah begitu besar, masih di bawah $1 \%$ dari nilai PDB mereka, terendah keempat setelah Romania, Latvia dan Slovak Republic. Catatan patut diberikan bagi France, dengan nilai R\&D Expenditures di atas 2\% dari nilai PDB mereka, negara tersebut mampu menghasilakan rata-rata sebanyak 14,524.625 permohonan paten dari penduduk mereka. Secara umum, selama periode penelitian, negaranegara yang menjadi sampel penelitian memiliki tingkat kelahiran perusahaan rata-rata sebesar $11.710 \%$.

Tabel 4. R Square \& VIF

\begin{tabular}{|c|c|c|c|}
\hline & \multirow[b]{2}{*}{$\begin{array}{c}\mathrm{R} \\
\text { Square }\end{array}$} & \multicolumn{2}{|c|}{ Log_Patent } \\
\hline & & RDE & $\begin{array}{c}\text { RDE } x \\
\text { Log Patent }\end{array}$ \\
\hline $\begin{array}{l}\text { Birth } \\
\text { Rate }\end{array}$ & 0.113 & 1.016 & 1,222 \\
\hline
\end{tabular}

Sumber : Data Olahan (2020)

Tabel 4 menunjukan bahwa nilai R-Square berada pada nilai 0.113 .
Hal ini menunjukkan bahwa aktivitas inovasi yang diwakili oleh R\&D Expenditures dan jumlah permohonan paten dapat mempengaruhi tingkat kelahiran perusahaan sebesar $11.3 \%$. Angka tersebut mennjukan bahwa model peneltian dalam kategori lemah (Hair et al., 2010). Sedangkan nilai VIF digunakan untuk menandai ada atau tidaknya gejala multikolinieritas antara variabel penelitian yang digunakan, dengan nilai ambang batas maksimalnya adalah 5 (Garson, 2016). Dari tabel 4 diketahui bahwa semual nilai VIF variabel penelitian lebih rendah dari 5 , sehingga dapat disimpulkan bahwa variabel-variabel penelitian yang digunakan terbebas dari persoalan multikolinieritas.

Tabel 5 Hasil Uji Statistik/Bootstrapping SmartPLS

\begin{tabular}{lrl}
\hline Hubungan Variabel & $\begin{array}{c}\text { T } \\
\text { Statistics }\end{array}$ & P Values \\
\hline RDE -> Birth Rate & 4.059 & 0.000 \\
\hline $\begin{array}{l}\text { RDE x Log_Patent -> Birth } \\
\text { Rate }\end{array}$ & 0.859 & 0,391 \\
\hline \multicolumn{2}{l}{ Sumber : Hasil Olahan PLS (2020) } &
\end{tabular}

Hasil bootstraping PLS menemukan koeefisien jalur RDE dengan Birth Rate sebesar - 0.314 serta nilai $\mathrm{p}<0.01$. Hal ini mengungkapkan bahwa RDE berpengaruh negatif terhadap tingkat kelahiran perusahaan, yang artinya setiap peningkatan nilai RDE maka akan dapat menurunkan tingkat kelahiran perusahaan, begitupun sebaliknya. Meskipun nilai $\mathrm{p}$ value yang daoat lebih kecil dari 0.05, namun karena hasil penelitian menunjukan pengaruh dengan arah yang negatif, maka dengan demikian dapat dinyatakan bahwa hasil penelitian ini tidak mendukung atau menolak hipotesis 1. Sedangkan untuk hiptesis kedua, didapatkan koefisien jalur 0.095, denga $p$-value $>0.05$. Dengan demikian dapat dinyatakan bahwa hasil penelitian 
ini juga tidak mendukung atau menolak hipotesis kedua.

Tujuan dari penelitian ini salah satunya adalah untuk memahami untuk memahami bagaimana pengaruh inovasi terhadap tingkat kelahiran perusahaan, demi melihat keefektifan inovasi yang dilakukan sebuah negara dalam meningkatkan jumlah entrepreneur di negaranya. Inovasi dapat menjadi motivasi untuk memulai sebuah perusahaan baru (Colombelli et al., 2016). Namun sayangnya hasil penelitian ini tidak mendukung hal tersebut, yang artinya aktivitas R\&D yang dilakukan di negara-negara yang menjadi sampel penelitian tidak dapat menciptakan peluang untuk bermunculannya perusahaanperusahaan baru di negara mereka. Hal ini bertolak belakang dengan pernyataan yang mengatakan bahwa aktivitas inovasi dapat mendukung bermunculannya startup pada sektorsektor baru (Dejardin, 2011)

Hasil penelitian ini setidaknya mengindikasikan beberapa hal. Pertama, bahwa aktivitas inovasi yang dilakukan oleh negara-negara yang menjadi sampel penelitian, terutama aktivitas R\&D tidak terbukti aplikatif dalam menuntun para calon pengusaha untuk menciptakan produk-produk baru. Kedua, kurangnya kolaborasi atau kerja sama inovasi dari beberapa perusahaan atau institusi, sehingga mengecilkan kemungkinan untuk bermunculannya model bisnis baru dengan merek atau nama perusahaan baru.

Indikator sebuah negara melakukan inovasi yang bisa dikatakan apilkatif adalah banyaknya bermunculan aplikasi paten di negara tersbut. Dengan dipatenkannya sebuah hasil dari aktivitas inovasi, maka hal itu menandakan kesiapan dari aktivitas inovasi tersebut untuk dikomersialisasikan dalam bentuk produk-produk baru. Jika hal ini terjadi, tentunya akan memperbesar peluang bermunculannya perusahaanperusahaan baru di negara tersebut. Hasil penelitian ini membuktikan bahwa dengan adanya aplikasi paten yang memodoreasi hubungan aktivitas R\&D dengan angka kelahiran perusahaan dapat mengubah arah pengaruhnya yang semula negatif menjadi positif, meskipun tidak signifikan secara statistik.

Adapun implikasi dari hasil penelitian ini bagi para pegambil kebijakan di sebuah negara adalah mereka perlu mendorong perusahaanperusahaan besar untuk mau berkolaborasi dengan calon-calon pengusaha baru, seperti contohnya dengan inkubator-inkubator bisnis yang ada di negaranya. Salah satu cara yang dapat dilakukan adalah dengan memberikan insentif fiskal seperti hibah, pengadaan publik, pinjaman, jaminan serta insentif pajak (OECD, 2015). Setiap satu dollar insentif pajak yang diberikan telah meningkatkan pengeluaran perusahaan untuk aktivitas R\&D. Namun sekali lagi kami perlu memberikan catatan, bahwa sebaiknya insentifi fiskal yang diberikan untuk juga difokuskan bagi perusahaanperusahaan yang mau menggandeng dan bekerjasama dengan calon-calon pengusaha atau perusahaan-perusahaan kecil untuk melakukan aktivitas R\&D.

\section{PENUTUP \\ Kesimpulan}

Inovasi dapat dilihat dari dua sisi, yaitu sisi kerberhasilannya dan sisi kegagalannya. Penelitian ini mencoba melihat kerberhasilan inovasi dari sisi keefektifannya dalam menghasilkan perusahaan-perusahaan baru, dengan menggunakan data makro di beberapa negara, yaitu nilai belanja R\&D, aplikasi paten, dan angka kelahiran 
perusahaan. Aktivitas R\&D sebuah negara bisa dikatakan efektif jika dapat menciptakan produk-produk baru dengn merek maupun nama perusahaan baru. Hasil penelitian ini membuktikan bahwa aktivitas R\&D yang dilakukan negaranegara yang mejadi sampel penelitian R\&D terbukti tidak efektif dan aplikatif dalam menciptakan pengusahapengusaha baru. Seharunya semakin aplikatif aktivitas R\&D yang dilakukan maka dapat dengan mudah diadopsi dan dipraktikan untuk diproduksi serta dikomersialisasikan. Namun hasil penelitian justru menunjukkan gejala yang sebaliknya, dimana semakin meningkatnya R\&D Expenditures, justru akan dapat menurunkan angka kelahiran perusahaan-perusahaan baru.

\section{Saran}

Penelitian ini tentunya memiliki keterbatasan yang dapat dipenuhi oleh penelitian selanjutnya. Pertama, penelitian ini hanya menggunakan sampel sejumlah 16 negara anggota OECD. Jumlah ini hanya sekitar $44.44 \%$ dari jumlah anggota OECD, dan hanya sekitar $8.29 \%$ dari jumlah negara yang menjadi anggota united nations yang pada tahun 2011 tercatat sebanyak 193 negara. Dengan demikian tentu saja hasil penelitian ini tidak dapat digeneralisasi secara umum ke semua negara yang ada. Untuk itu penelitian berikutnya perlu menggunakan jumlah sampel yang lebih besar dan tersebar di beberapa benua yang ada di dunia. Jika memungkinkan akan lebih baik penelitian selanjutnya juga memisahkan antara negara maju, negara berkempang serta negara dunia ketiga, sehingga didapatkan hasil dan analisis yang lebih tajam terkait dengan kebijakan inovasi dan dampaknya di setiap kelompok negara tersebut. Kedua, data R\&D Expenditures yang digunakan adalah data secara agregat pada sebuah negara, baik itu R\&D Expenditures yang dikeluarkan oleh pemerintah, perusahaan swasta maupun universitas. Untuk itu penelitian selanjutnya perlu memisahkan R\&D Expenditures untuk ketiga sektor tersebut. Tujuannya adalah untuk memperkuat hasil pada penelitian ini yang menyatakan tidak efektifnya aktivitas R\&D yang dilakukan sebuah negara dalam meningkatkan jumlah entrepreneur di negaranya, terutama aktivitas R\&D yang dilakukan oleh pemerintah dan universitas.

\section{Ucapan Terima Kasih}

Penelitian ini sepenuhnya didukung dan dibiayai oleh Kementrian Pendikan dan Kebudayaan Republik Indonesia, Badan Riset dan Inovasi Nasional, Tahun Anggaran 2020 dengan nomor kontrak: 107/SP2H/PPM/DRPM/2020

\section{DAFTAR PUSTAKA}

Bennett, D., Collinson, G., Edbury, M., Surkovic, E., and Wardle, J. (2014). Innovation: Managing Risk, Not Avoiding It, Evidence and Case Studies. Annual Report of the Government Chief Scientific Adviser 2014, Government Office for Science.

Colombelli, A., Krafft, J., \& Vivarelli, M. (2016). Entrepreneurship and Innovation: New Entries, Survival, Growth. GREDEG Working Papers Series, No. 2016-04.

Como, E., Mathis, A., Tognetti, M., \& Rapisardi, A. (2016). Cooperative Platforms In A European Landscape: An Exploratory Study. ISIRC Conference, Glasgow, September 2016.

Dejardin, M. (2011). Linking Net Entry to Regional Economic Growth. 
Small Business Economics, 36 (4), 443-60.

Fitzsimons, P., \& O'Gorman, C. (2017).

The 2016 Survey of Entrepreneurship in Ireland. Global Entrepreneurship Monitor (GEM).

Garson, G.D. (2016). Partial Least Squares (PLS-SEM): 2016 Edition. Statistical Associates Publishing, Asheboro.

Hair, J.F.JR., Anderson, R.E., Tatham, R.L., \& W.C. Black. (2010). Multivariate Data Analysis. Seventh edit. Prentice Hall Internatiional, inc.

Helmers, C., \& Rogers, M. (2010). Innovation and the Survival of New Firms in the UK. Rev Ind Organ (2010) 36, 227-248.

ITU. (2016). A review of Micro, Small and Medium Enterprises in the ICT Sector 2016. International Telecommunication Union, Geneva.

OECD. (2015). The Innovation Imperative: Contributing to Productivity, Growth and WellBeing. OECD Publishing, Paris. http://dx.doi.org/10.1787/97892 64239814-en.

Welfens, P., J., J. (2011). Innovations in Macroeconomics, 3 rd Edition. Springer. 